\title{
The comparison of solar installation heat gains and SHW simulation results - case study
}

AbSTRACT: In Poland an increase in the of number solar thermal collectors is observed in household applications. For economic and ecological profitability the creation of a solar thermal installation design in a proper manner is essential.

In order to determine solar installations size, software calculating future solar heat gains is used. SHW software is an examples of such software. The aim of this work was to compare the simulation results with the real results of the solar installation operation. The comparison was performed by an example of a single-family house with flat plate collector installations located in south-east Poland. This installation supports domestic hot water preparation in a house occupied by four people (in two-year period of analyses). The additional heat source in this building is a gas boiler. Solar fraction parameter values were chosen for this comparison. Solar fraction is calculated as a ratio of solar heat gains used in the domestic hot water preparation process to the heat desired for domestic hot water preparation. The real results of Solar Fraction turned out to be higher than the simulation results from May to August (there were many days with Solar Fraction =1). A difference of 20-50 percentage points was observed (Solar Fraction). Apart from this period no special differences were observed.

$\triangle$ Corresponding Author: Piotr Olczak; e-mail: olczak@min-pan.krakow.pl

1 Mineral and Energy Economy Research Institute of the Polish Academy of Sciences, Kraków, Poland; ORCID iD: 0000-0002-4926-0845; e-mail: olczak@min-pan.krakow.pl

2020. The Author(s). This is an open-access article distributed under the terms of the Creative Commons Attribution-ShareAlike International License (CC BY-SA 4.0, http://creativecommons.org/licenses/by-sa/4.0/), which permits use, distribution, and reproduction in any medium, provided that the Article is properly cited. 
Additionally analyses of differences between solar heat gains calculated by Get Solar simulation software with real values (for analyzed building) was performed. This simulation analysis was done before process of building installations.

KEYwORDS: simulation, renewable energy, solar energy, flat plate collector, solar thermal

\section{Introduction}

In Poland, the number of installations supporting the preparation of domestic hot water (DHW) using solar collectors has been growing for years (in 2018, 1.24 GW of power was installed in flat-plate collectors) (Olczak et al. 2020; Weiss and Spörk-Dür 2018). This increase is associated with the growing popularity of Renewable Energy Sources and the desire to reduce the phenomenon of low emissions (Jeleński et al. 2020; Kryzia and Pepłowska 2019). Single-family home users can take advantage of the limited possibilities of clean heat production. These methods are: heat pumps, solar collectors, PVT (Calise et al. 2019), cogeneration as biomass and natural gas (Kryzia et al. 2020; Matuszewska et al. 2017) and geothermal heat only in selected areas (Pająk et al. 2020). The selection of renewable energy sources is connected with conducting a simulation of heat production in relation to internal (mainly heat demand, heat temperature required) and external conditions (such as: ambient temperature, wind speed, solar radiation density) (Canales et al. 2020). Heat source technology (mainly renewable energy source) can be rarely produced heat directly suitable to the heat demand. Therefore in many cases the unevenness of the heat demand and its production may cause the need to accumulate its surpluses in ordinary or extended storage tanks, e.g. with PCM materials (Kuta et al. 2016; Sacharczuk and Taler 2019). In order to properly choose the size of the installation and components, the following programs are used, among others: GetSolar (ETU 2020) and SHW (UIBK 2017) analyzed in this paper. The analysis used measured data recorded in a single-family building, for which the daily average heat needed to prepare domestic hot water is $7.6 \mathrm{kWh} /$ day (Olczak et al. 2015).

Good et al. compared simulation results and measured results from solar thermal installation using a solar fraction parameter in a net zero energy building in Trondheim (Good et al. 2015). Hartmann et al. compared solar thermal installation results with the simulation (TRNSYS) for a typical small office building located in Freiburg and in Madrid (Hartmann et al. 2011). TRNSYS was also used in case of adoption of micro-scale renewable energy systems in the residential sector (Figaj et al. 2020). Hsieh et al. used quasi-steady state simulation models in order to evaluate solar thermal systems in Switzerland (Hsieh et al. 2017). However, there is lack of research in solar thermal installations compared with simulation analyses conducted in Polish climate conditions.

The aim of the article is to compare the results of a simulation carried out in one of the programs with the actual results achieved in the solar installation as a part of hot water preparation system. The indirect goal is to show that the analyzed program is the right tool to design the size of solar thermal installations in Poland. 


\section{Solar Installation}

Solar collectors in Poland are often installed in single-family houses, in which they process solar energy usually for the purpose of preparing DHW. Collectors are assembled both in newly-built buildings and in the existing ones. In both cases, choosing the installation size is important. Estimating whether the selection has been properly made is only possible after several years of use. The paper analyses the results from the SHW simulation program in comparison with the performance of the solar installation data.

A single-family house, located $50 \mathrm{~km}$ east of Krakow, was selected for the analysis conducted from June 1, 2014 to May 31, 2016. This area in Poland is characterized by the following insolation and weather conditions (Fig. 1). The insolation (for the entire year) in typical reference year is $1094 \mathrm{kWh} /\left(\mathrm{m}^{2} \cdot\right.$ year $)$.

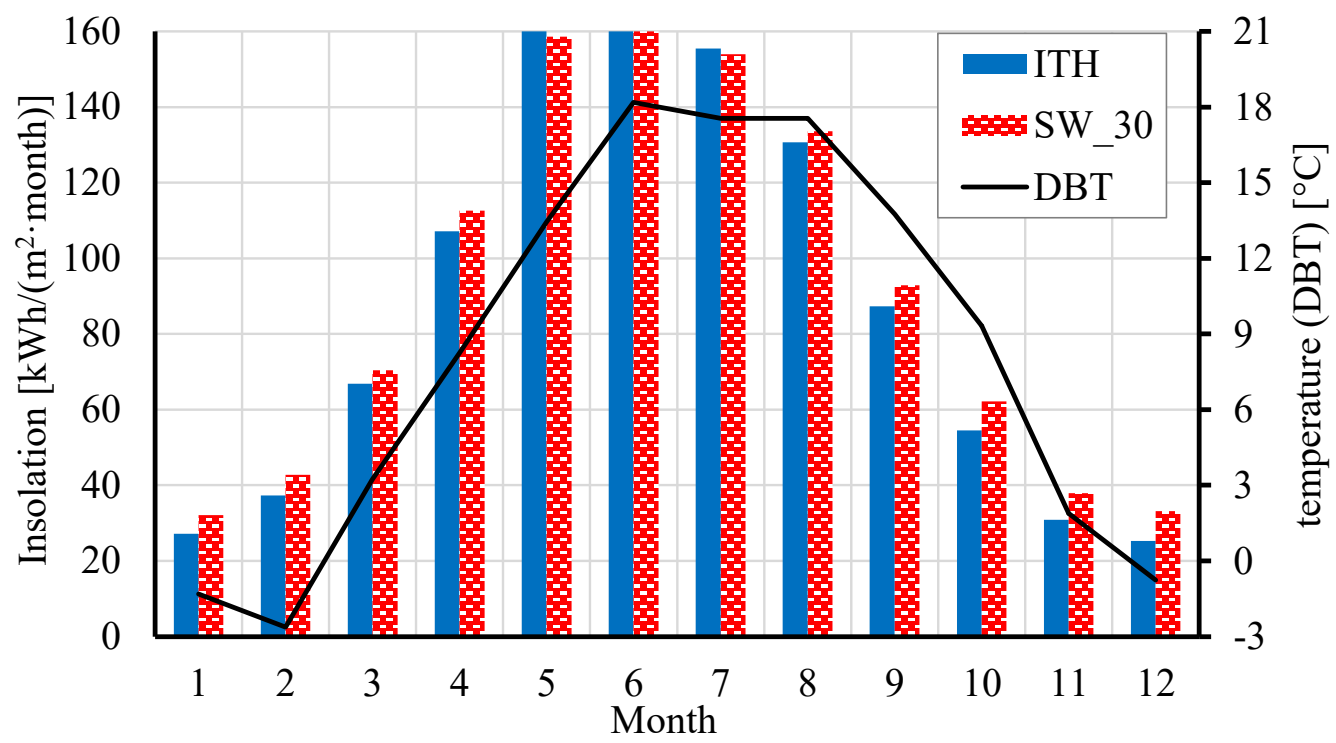

Fig. 1. Insolation on the horizontal plane (ITH), insolation on the plane directed towards the south-west with an inclination angle of $30^{\circ}$ (SW_30) and average monthly ambient temperature (DBT). ITH, SW 30, DBT come from Typical Reference Year (Krakow) Source: own study based on Typical Reference Year (Ministry of Development 2019)

Rys. 1. Nasłonecznienie na płaszczyznę poziomą, nasłonecznienie na płaszczyznę nachyloną w kierunku południowo-zachodnim pod kątem $30^{\circ}$ oraz temperatura zewnętrzna dla Krakowa

The building (Fig. 2) was built in 1986 and in 2012 solar collectors were installed in order to support the domestic hot water preparation system, in which the gas boiler plays the major role. Gas in this house is used only for hot water preparation and central heating. The general scheme 
of the extended system is presented in the chapter devoted to simulation (Fig. 6). The number of hot water users in house in the analyzed period was four.

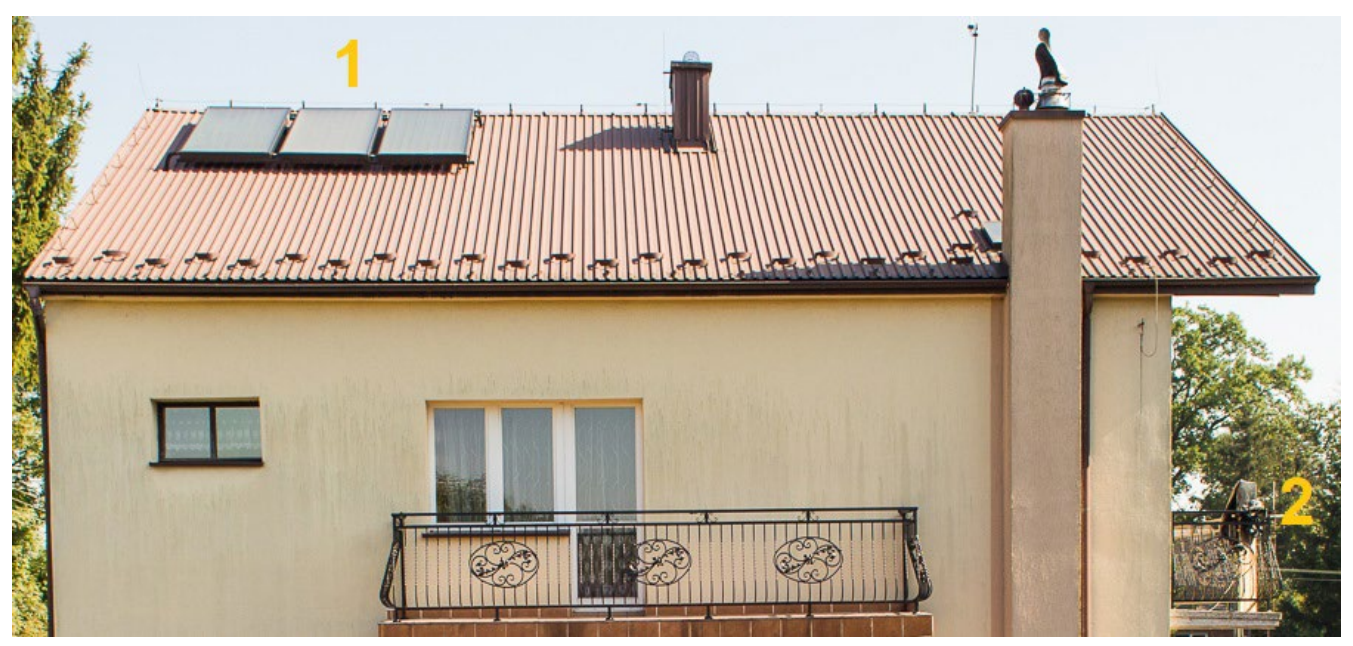

Fig. 2. Analyzed building with solar collectors (1) and solar radiation density meter (2). This picture shows the south-west side of the building Source: own study

Rys. 2. Analizowany budynek z kolektorami słonecznymi (1) i miernikiem natężenia promieniowania słonecznego (2). Zdjęcie pokazuje południowo-zachodnią stronę budynku

The main components of the solar installation include:

$\downarrow 3$ solar flat-plate collectors with the total absorber area of $5.61 \mathrm{~m}^{2}$ and efficiency coefficients: $\eta_{0}=0.751 ;$ a $1=4.999 \mathrm{~W} /\left(\mathrm{m}^{2} \cdot \mathrm{K}\right)($ Biawar 2012; Olczak 2020). These collectors have a south-west orientation and a thirty-degree angle of inclination to the ground,

$\checkmark$ Pipeline connecting the hot water storage tank with the roof collectors. This pipeline is made of copper and its diameter is $18 \mathrm{~mm}$ with additional $13 \mathrm{~mm}$ isolation. The pipeline length is $15 \mathrm{~m}$,

$\checkmark 55 \mathrm{~W}$ circulation pump, including accessories and safety valves,

$\downarrow$ Automation devices. Set value for start circulation is $9 \mathrm{~K}$ (solar collector temperature - hot water tank temperature) and for stop circulation is $7 \mathrm{~K}$.

$\checkmark 210 \mathrm{dm}^{3}$ hot water storage tank equipped with two coils (The characteristic of heat losses from that hot water tank is presented in the work (Olczak 2020)). 


\section{Measuring system}

In the analyzed period, the installation was equipped with the following devices:

$\checkmark$ solar radiation density meter Pyranometer Eppley (EPLAB 2015), positioned on a horizontal plane, shown in Figures 2 and 3. Additional equipment for the installation only during the test period,

- Solar energy gains meter (basic equipment installation measuring the heat supplied to the lower part of hot water storage tank and integrated with the solar controller) (Instalreporter 2020),

$\checkmark$ Heat meter (Danfoss EEM-C CAL STREEM) responsible for measuring the heat supplied to the upper coil of the solar cylinder (Metbox 2020). Additional equipment installed permanently in December 2014,

$\checkmark$ Thermocouple thermometers including a data recorder. Additional equipment for the installation only during the selected periods of 2015 (PROVA 2020),

$\checkmark$ Electricity Meter Accessories permanently installed in May 2014,

$\checkmark$ "Intergaz" gas meter permanently installed in the house (Intergaz 2020).

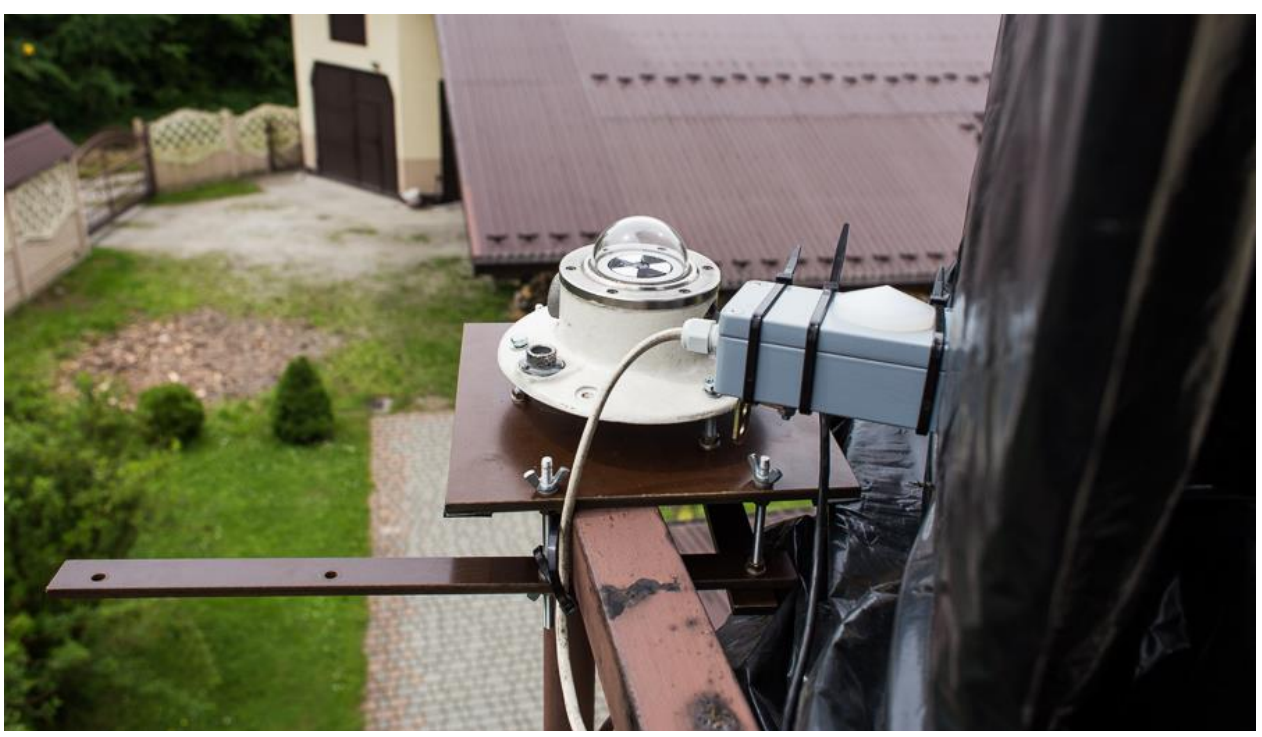

Fig. 3. Eppley solar radiation density meter Source: own study

Rys. 3. Miernik natężenia promieniowania słonecznego firmy Eppley

On the basis of the data collected from the measuring devices, the solar energy, the used electricity, and the efficiency of the solar energy thermal performance were determined. The results are shown in Figure 4. 


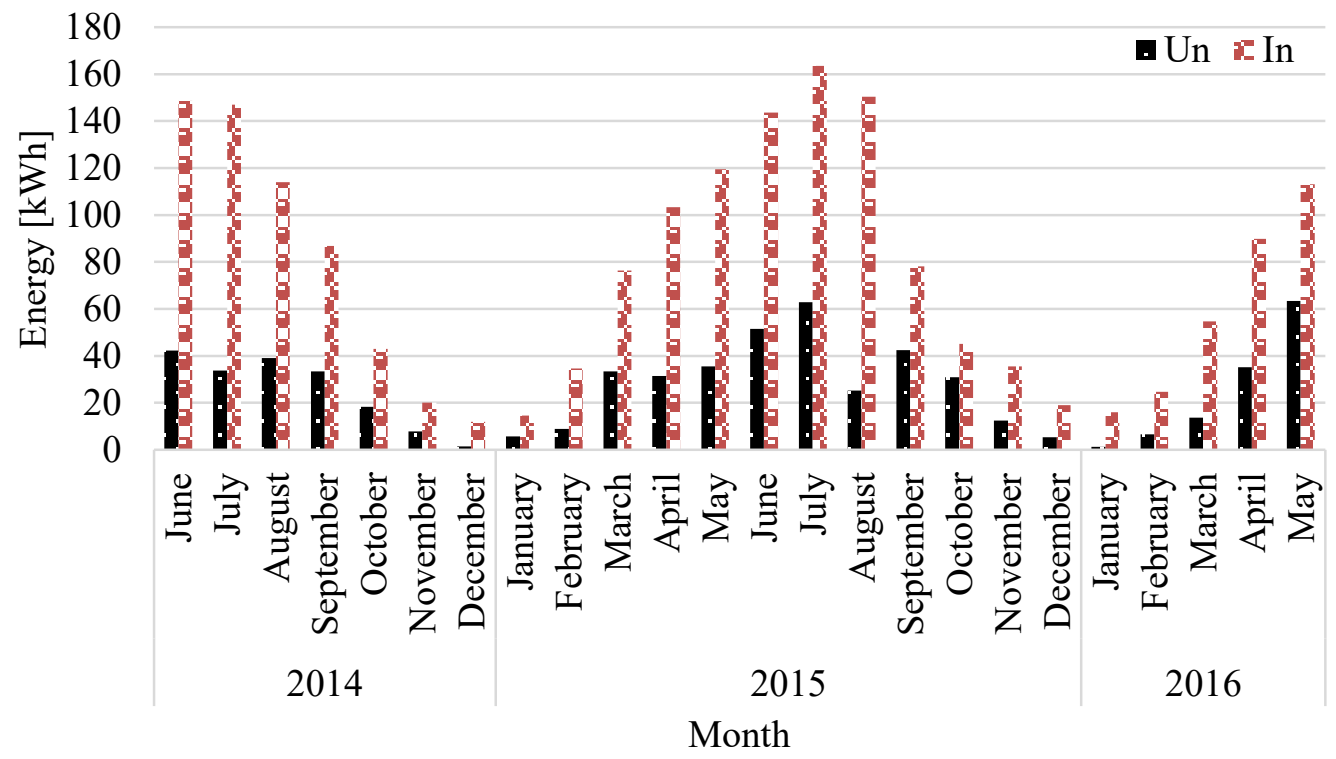

Fig. 4. Solar heat gains per month (Un) and the measured monthly insolation (In) Source: own study

Rys. 4. Miesięczne uzyski solarne (Un) i zmierzone miesięczne nasłonecznienie (In)

In the analyzed period, about $126 \mathrm{kWh}$ of electricity was used for the operation of the solar system circulation pump and its automatics. Solar heat gains in this period amounted to $3600 \mathrm{kWh}$. The share of consumed electricity in relation to solar heat gains was 3.5\%. It is more than the typical average value (1-2\%) (Olczak et al. 2018; Olczak and Zabagło 2015) and one of reasons of such a situation is that a non-save energy circulation pump was used.

In the analyzed period, $33 \%$ of solar energy thermal efficiency was achieved. That efficiency was calculated as the total solar heat gains divided by the measured insolation in the horizontal plane.

\section{Simulation of the solar installation effects}

\subsection{GetSolar}

Before the investment, the simulation was conducted by the solar system manufacture (software GetSolar 9.0) (ETU 2020). This simulation was based only on the number of users and the location of the installation. The average daily heat amount needed for DHW was obtained 
as $10.3 \mathrm{kWh} /$ day (higher than in the real case (Olczak et al. 2015)). The simulation results were shown in Figure 5.

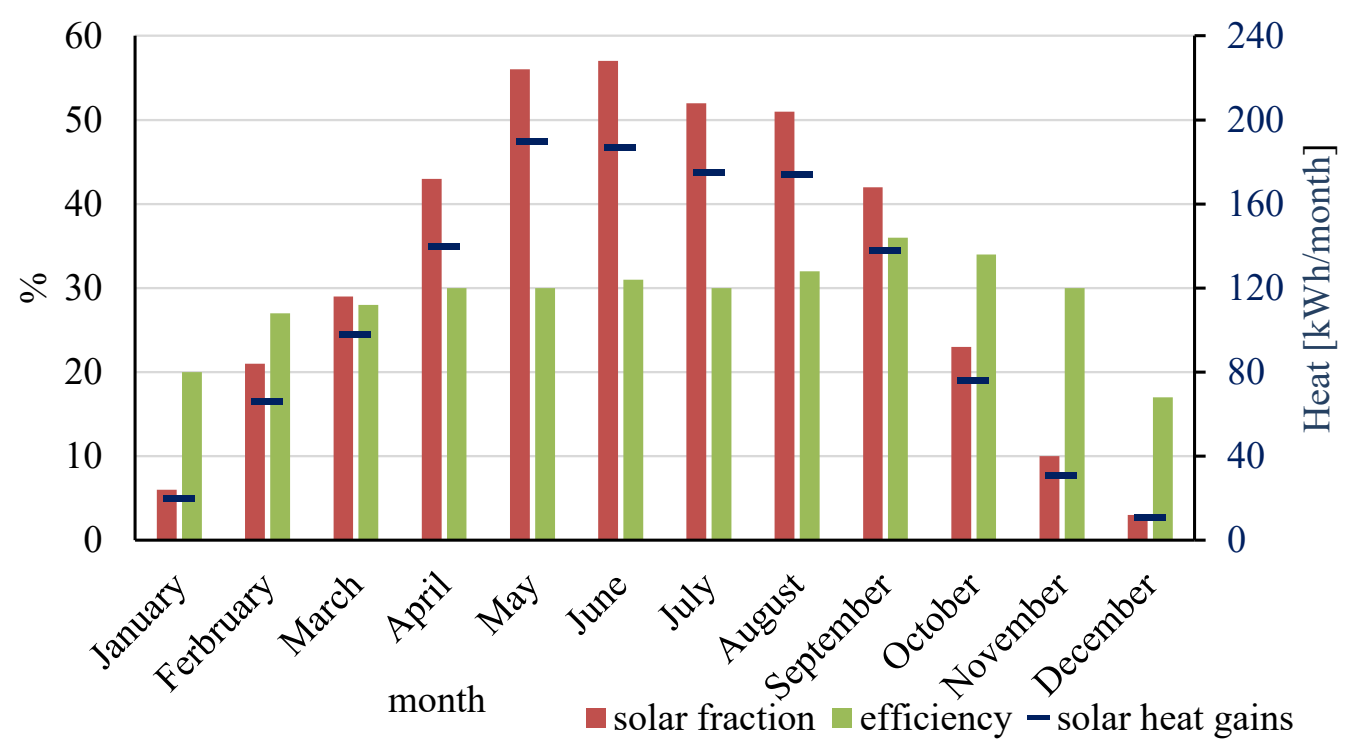

Fig. 5. Solar fraction, efficiency and solar heat gains as results from GetSolar Source: own study

Rys. 5. Udział energii solarnej, efektywność i uzyski ciepła jako wyniki z programu GetSolar

\subsection{SHW}

The SHW software (version 10/2016) was written by W. Streicher, D. Siegele, A. Thuer, K. Schnedl, R. Kouba (Arbeitsbereich Energieeffizientes Bauen, Universität Innsbruck) (UIBK 2017). This program is more technologically advanced and more accurate than GetSolar and, therefore, it was used for the analysis.

Knowing the already used solar installation construction (schema - Fig. 6) and its operation, the simulations of the thermal effects were conducted using the SHWsoftware. The following assumptions were made:

Collector: Conversion Factor 0.751 Heat Transfer Coefficient: $4.999 \mathrm{~W} /\left(\mathrm{m}^{2} \cdot \mathrm{K}\right), 3^{\text {rd }}$ Parameter of the Collector Characteristic Curve $0 \mathrm{~W} /\left(\mathrm{m}^{2} \cdot \mathrm{K}^{2}\right.$ ); Absorber Area $5.61 \mathrm{~m}^{2}$ (Hevelius wunder n.d.), Inclination $30^{\circ}$, Azimuth $-45^{\circ}$, Control of the Collector Massflow - Fixed Mass Flow.

Pipes: Length HX-Col $15 \mathrm{~m}$ and Col-HX $15 \mathrm{~m}$, diameter $18 \mathrm{~mm}$, Insulation Thickness $0.013 \mathrm{~m}$.

Storage volume $220 \mathrm{dm}^{3}$, Height $1.5 \mathrm{~m}, 0.08 \mathrm{~m}$ insulation thickness. The issue of heat losses from the Hot Water Tank is described in (Olczak 2020). 


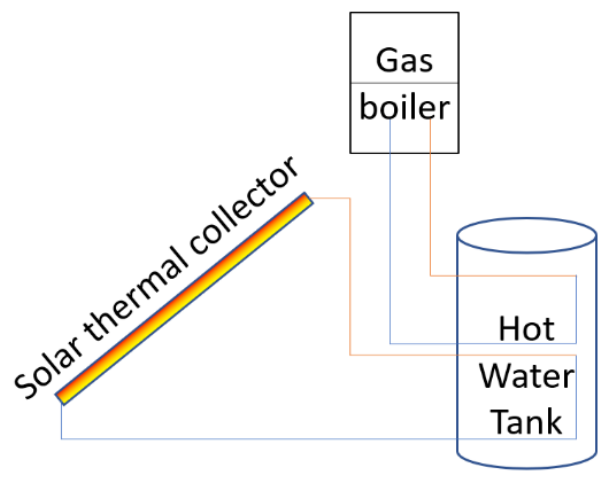

Fig. 6. Scheme of the hot water preparation installation Source: own study based on SHW (UIBK 2017)

Rys. 6. Schemat instalacji przygotowania ciepłej wody użytkowej

In order to conduct the simulation analysis, the estimation of the average DHW quantity needed per day or the heat average daily requirement for the DHW preparation (QD) is important. The test equipment (mentioned in chapter 2) did not include any measuring devices that would allow us to determine the daily use of the DHW quantity. However, the heat needed to prepare DHW was estimated. The estimation of QD was based on the measurement data from May 2015 (Fig. 7) and it was assumed to be a constant value (7.3 kWh/day) during the year (Olczak et al.

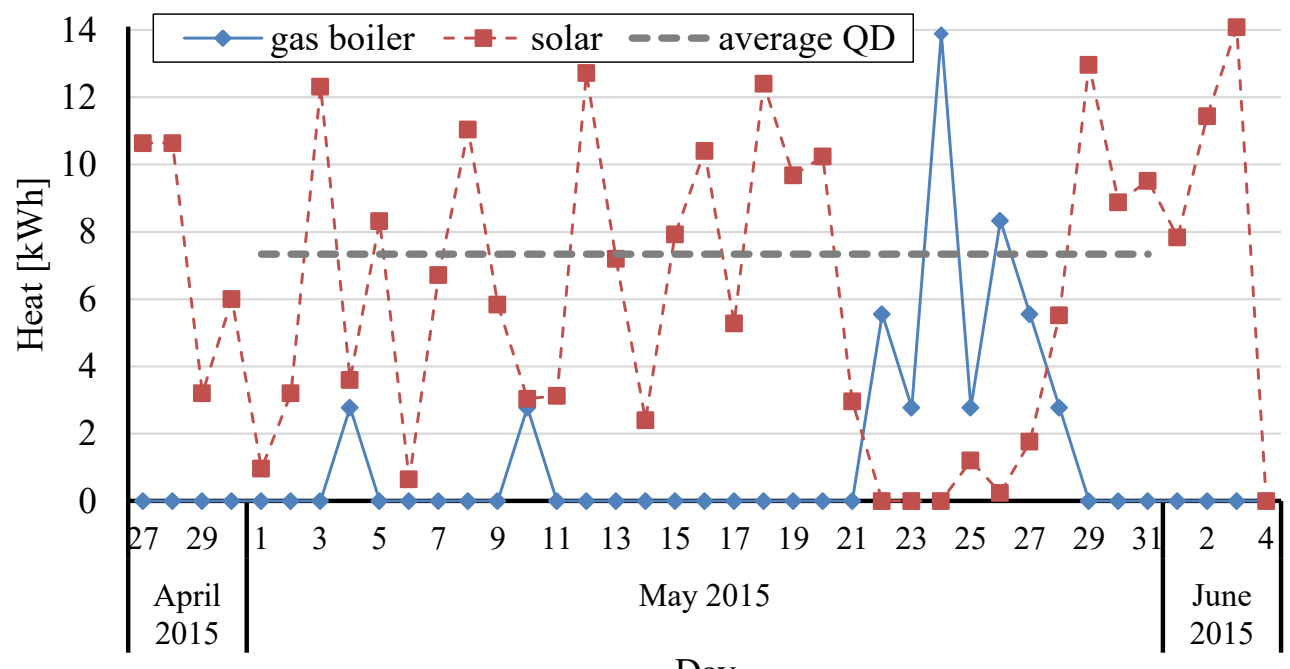

Day

Fig. 7. Heat delivered to the hot water tank (during May 2015)

Source: own study based on (Olczak et al. 2015)

Rys. 7. Ciepło dostarczone do zasobnika ciepłej wody użytkowej (maj 2015) 
2015). The heat demand was converted into hot water quantity demand, which gave $80 \mathrm{dm}^{3} /$ day. During the calculation, the estimated values of heat losses from the hot water tank (Olczak 2020) were taken into consideration and, additionally, it was assumed that the cold water temperature inlet equals $12^{\circ} \mathrm{C}$ and the outlet equals $42^{\circ} \mathrm{C}$ (the assumption was made on the basis of measurements conducted in May 2015) (Olczak et al. 2015, 2020).

\section{SHW simulation and real results}

The SHW software includes the following formula to calculate the solar fraction (Good et al. 2015; UIBK 2017):

$$
S F=1-\frac{\text { Qaux }}{\text { Quse }}
$$

where:

Quse - heat needed to prepare DHW (e.g. for one day it equals QD),

Qaux - heat produced by the gas boiler to prepare DHW.

For the real results (from a one-month period) $\mathrm{SF}=\mathrm{Qsol} / \mathrm{QD}$ for month was used, because the heat meter for Qaux wasn't installed from the first day of the analyzed period. These results are shown in Figure 8, but for the period from May to September 2015 and for May 2016, the results i.e. SF, Qaux were shown in Table 1.

TABLE 1. The measured results for the period from May to September 2015 and May 2016

TABELA 1. Zmierzone wyniki dla okresu od maja do września 2015 i dla maja 2016

\begin{tabular}{|c|l|c|c|c|}
\hline Year & \multicolumn{1}{|c|}{ Month } & $30 * \mathrm{QD}[\mathrm{kWh} /$ month $]$ & Qaux [kWh/month] & SF real \\
\hline \multirow{5}{*}{2015} & May & 220 & 47.2 & 0.79 \\
\cline { 2 - 5 } & June & 220 & 0.0 & 1.00 \\
\cline { 2 - 5 } & July & 220 & 2.8 & 0.99 \\
\cline { 2 - 5 } & August & 220 & 2.8 & 0.99 \\
\cline { 2 - 5 } & September & 220 & 83.3 & 0.62 \\
\hline 2016 & May & 220 & 0.0 & 1.00 \\
\hline
\end{tabular}

Similar results can be observed in the case of autumn and winter months whereas the biggest differences are visible in spring and summer. The differences between the measured solar fraction and the SHW simulation solar fraction was in February (less than 5 percent points) but in July it was close to 50 percentage points. 


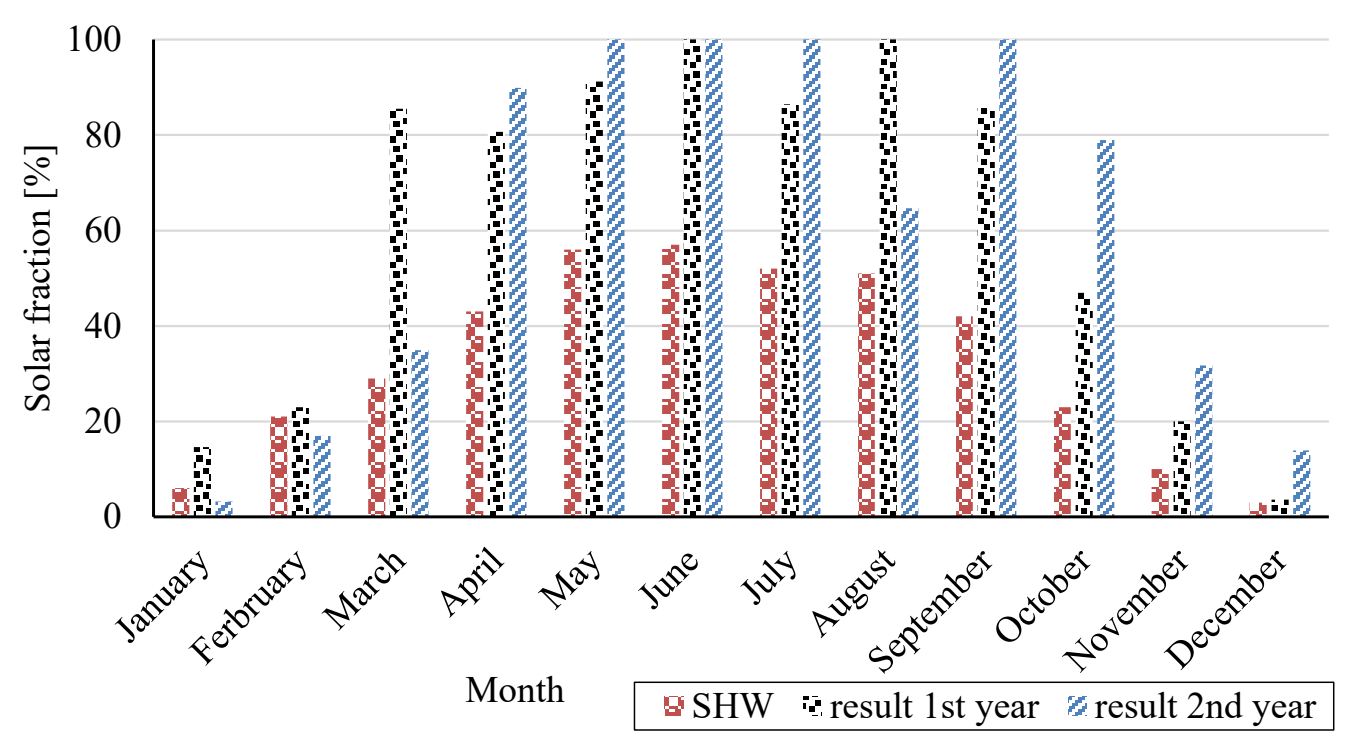

Fig. 8. The Comparison between the real results and the SHW simulation Source: own study

Rys. 8. Porównanie pomiędzy rzeczywistymi wynikami a pochodzącymi z symulacji SHW

The reasons for such a situation are:

$\downarrow$ it is impossible to measure the exact amount of hot water used by all inhabitants of the house, and also it is difficult to check the exact time when hot water is used and enter this combined data into the program,

$\downarrow$ heat demand for hot water preparation in the analyzed building is correlated with radiation because it is located in the countryside and thus, household chores and gardening works are frequent,

$\checkmark$ data about the insolation taken into consideration in the SHW sfotware results from a typical reference year (counted on the basis of the weather station data collected for many years). The real results, on the other hand, come from a selected two-year period,

$\downarrow$ the direct sequence of days with low insolation is also important, as the lack of relatively high insolation for several days ( $>4 \mathrm{kWh} / \mathrm{m}^{2} /$ day) requires the use of a different heat source. The length of this period (days with a relatively small amount of daily insolation) combined with the amount of the DHW heat demand determines the size of the hot water tank as well as the solar fraction.

Solar heat gains shown in Figure 9 are the main outcome of insolation and other external and internal conditions. May and September were only presented because of relatively big differences between the SHW simulation results and the real results shown in Figure 8.

It was observed that apart from a few days in May 2015 (22-27) the break in the heat supply coming from the solar system did not last longer than 2 days. 


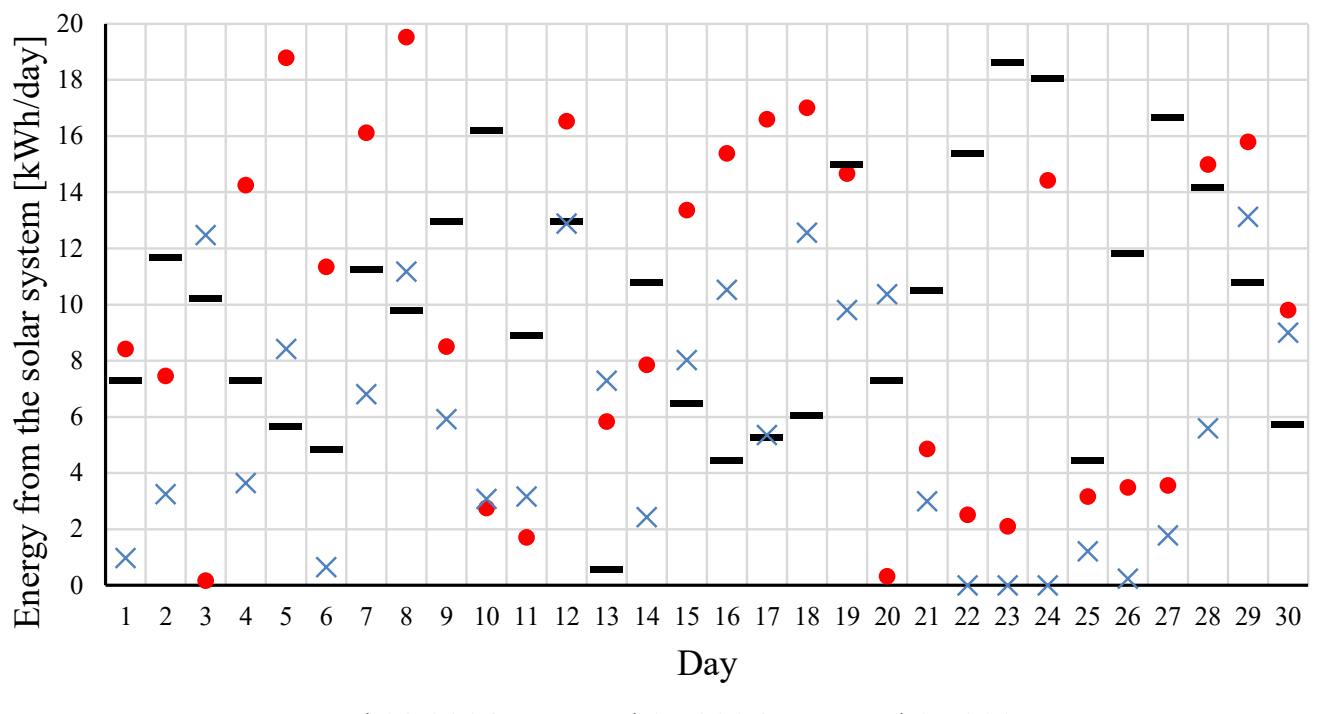

- Qsol 09.2014 —Qsol 05.2016 ×Qsol 05.2015

Fig. 9. Energy measured for the solar system for a chosen time period

Source: own study

Rys. 9. Energia zmierzona w systemie solarnym dla wybranych okresów

\section{Conclusions}

The real results measured (solar fraction, solar heat gains) in the flat-plate collector installation in the detached house in Lesser Poland were higher than in simulations cases (GetSolar and SHW).

Averaging the values taken into account in the calculations in the simulation program is insufficient for calculating the solar energy produced and used in solar/DHW installation, because the range of results such as the solar fraction in several months (mainly when the produced solar heat was the higher) differed close to 50 percentage points. Additionally, results from SHW simulation indicate that the size of flat-plate collectors could be higher but in real cases this was not confirmed. The real Solar fraction of almost $100 \%$ during spring and summer period could not be improved by increasing the flat-plate collectors size. 


\section{Literature}

Biawar 2012. BIAWAR solar set installation manufacturer's offer. Cracow, p. 4.

CAlise et al. 2019 - Calise, F., Figaj, R.D. and VAnOli, L. 2019. Energy performance of a low-cost PhotoVoltaic/Thermal (PVT) collector with and without thermal insulation. IOP Conference Series: Earth and Environmental Science 214, p. 012116.

Canales et al. 2020 - Canales, F.A., Jadwiszczak, P., Jurasz, J., Wdowikowski, M., Ciapala, B. and KAŹMIERCZAK, B. 2020. The impact of long-term changes in air temperature on renewable energy in Poland. Science of the Total Environment 729, p. 138965.

EPLAB 2015. Black \& White Pyranometer. [Online] http://www.eppleylab.com/wp-content/uploads/pdf/ EPPLEY160919-8-48-Diffuse.pdf [Accessed: 2020-01-05].

ETU 2020. GetSolar 9.0. [Online] https://www.etu-software.com/M/SOFTWARE/Renewables-Simulation/GetSolar-Professional/Seite.html,154166,96653 [Accessed: 2020-08-20].

Figaj et al. 2020 - Figaj, R., ŻoŁąDeK, M. and Goryl, W. 2020. Dynamic Simulation and Energy Economic Analysis of a Household Hybrid Ground-Solar-Wind System Using TRNSYS Software. Energies 13(14), p. 3523.

Good et al. 2015 - Good, C., Andresen, I. and Hestnes, A.G. 2015. Solar energy for net zero energy buildings - A comparison between solar thermal, PV and photovoltaic-thermal (PV/T) systems. Solar Energy 122, pp. 986-996.

Hartmann et al. 2011 - Hartmann, N., Glueck, C. and Schmidt, F.P. 2011. Solar cooling for small office buildings: Comparison of solar thermal and photovoltaic options for two different European climates. Renewable Energy 36(5), pp. 1329-1338.

Hevelius wunder n.d. [Online] http://www.biawar.com.pl/systemy-solarne/hevelius-wunder-kolektory-plaskie/hevelius-cls-3-bz [Accessed: 2020-08-20].

Hsien et al. 2017 - Hsien, S., Omu, A. and Orehounig, K. 2017. Comparison of solar thermal systems with storage: From building to neighbourhood scale. Energy and Buildings 152, pp. 359-372.

Instalreporter 2020. PLUM Ecosol 200 Regulatory. [Online] https://instalreporter.pl/produkty/regulator-ecosol-200/ [Accessed: 2020-08-20].

Intergaz 2020. BK-G4. [Online] https://www.intergaz.eu/produkty/gazomierze/miechowe/bk-g4m/ [Accessed: 2020-08-20].

Jeleński et al. 2020 - Jeleński, T., Dendys, M., Tomaszewska, B. and PajĄK, L. 2020. The Potential of RES in the Reduction of Air Pollution: The SWOT Analysis of Smart Energy Management Solutions for Krakow Functional Area (KrOF). Energies 13(7), p. 1754.

Kryzia et al. 2020 - Kryzia, D., Kuta, M., MatuszewsKa, D. and OlczaK, P. 2020. Analysis of the potential for gas micro-cogeneration development in Poland using the Monte Carlo method. Energies 13(12), p. 3140.

Kryzia, D. and Peplowska, M. 2019. The impact of measures aimed at reducing low-stack emission in Poland on the energy efficiency and household emission of pollutants. Polityka Energetyczna - Energy Policy Journal 22(2), pp. 121-132.

Kuta et al. 2016 - Kuta, M., Matuszewska, D. and WójCiK, T.M. 2016. The role of phase change materials for the sustainable energy. E3S Web of Conferences 10, p. 00068.

Matuszewska et al. 2017 - Matuszewska, D., Kuta, M. and Górski, J. 2017. Cogeneration - Development and prospect in Polish energy sector. E3S Web of Conferences 14, p. 01021.

Metbox 2020. Danfoss Calstreem EEM-C. [Online] http://metbox.com/en/we_connect/Danfoss-Calstreem -EEM-C [Accessed: 2020-08-20]. 
Ministry of Development 2019. Typical Reference Year, Ministry of Development. [Online] https://www. gov.pl/web/fundusze-regiony/dane-do-obliczen-energetycznych-budynkow [Accessed: 2019-1218].

OlCZAK, P. 2020. The influence of excessive solar heat gains on heat loss in the hot water tank - case study. Polityka Energetyczna - Energy Policy Journal 23(2), pp. 91-104.

OlczaK et al. 2015 - OlczaK, P., Zabaglo, J., Kandefer, S. and Dziedzic, J. 2015. Influence of Solar Installation with Flat-Plate Collectors in a Detached House on Pollutants Emission and Waste Stream. Between Evolution and Revolution - in Search of an Energy Strategy, WAT, Poznań, pp. 739-752.

Olczak et al. 2018 - OlczaK, P., Kryzia, D., Augustyn, A. and Olek, M. 2018. The economic profitability of the changing size of solar collectors surface in the case study of the household domestic hot water installation. Zeszyty Naukowe Instytutu Gospodarki Surowcami Mineralnymi i Energia Polskiej Akademii Nauk 102, pp. 77-90.

Olczak et al. 2020 - Olczak, P., Matuszewska, D. and Zabaglo, J. 2020. The Comparison of Solar Energy Gaining Effectiveness between Flat Plate Collectors and Evacuated Tube Collectors with Heat Pipe: Case Study. Energies 13(7), p. 1829.

OlczaK, P. and Zabaglo, J. 2015. The Efficiency of the Solar System With Heat Pipe Collectors in Apartment Building. District Heating, Heating, Ventilation 11(46), p. 427.

Pająk et al. 2020 - Pają, L., Tomaszewska, B., Bujakowski, W., Bielec, B. and Dendys, M. 2020. Review of the Low-Enthalpy Lower Cretaceous Geothermal Energy Resources in Poland as an Environmentally Friendly Source of Heat for Urban District Heating Systems. Energies 13(6), p. 1302.

PROVA 2020. PROVA 800 Multi-Input Thermometer/Datalogger, PROVA. [Online] www.prova.com.tw/ product_detail.asp?seq=23 [Accessed: 2020-05-18].

SACHARCZUK, J. and TALER, D. 2019. Numerical and experimental study on the thermal performance of the concrete accumulator for solar heating systems Energy 170, pp. 967-977.

UIBK 2017. SHW - Simulation Software for Thermal Solar Systems. Universitat Innsbruck. [Online] https://www.uibk.ac.at/bauphysik/forschung/shw.html.en [Accessed: 2020-08-20].

WeIss, W. and SpörK-Dür, M. 2018. Global Market Development and Trends in 2018. Gleisdorf, Austria. www.mdpi.com/1996-1073/13/14/3523.

Piotr OlCZAK

\section{Porównanie uzysków ciepła z instalacji solarnej z symulacją - studium przypadku}

\section{Streszczenie}

W Polsce obserwuje się wzrost liczby kolektorów słonecznych w zastosowaniach domowych. Dla opłacalności ekonomicznej i ekologicznej ważne jest właściwe zaprojektowanie instalacji solarnej. W celu ustalenia wielkości instalacji słonecznych stosuje się oprogramowanie do obliczania przyszłych zysków ciepła słonecznego. Program SHW jest jednym z przykładów takiego oprogramowania. 
Celem pracy było porównanie wyników symulacji z rzeczywistymi wynikami pracy instalacji solarnej. Porównanie przeprowadzono na przykładzie domu jednorodzinnego (z instalacją płaskich kolektorów słonecznych) położonego w południowo-wschodniej Polsce. Instalacja solarna obsługuje przygotowywanie ciepłej wody użytkowej w domu zamieszkanym przez cztery osoby (w dwuletnim okresie analizy). Dodatkowym źródłem ciepła w tym budynku jest kocioł gazowy. Do porównania wybrano wartości parametru Solar Fraction. Solar Fraction jest obliczany jako stosunek zysków ciepła słonecznego wykorzystywanych w procesie przygotowania ciepłej wody użytkowej do ciepła pożądanego do przygotowania ciepłej wody użytkowej. Rzeczywiste wyniki frakcji słonecznej (w skali miesięcznej) okazały się wyższe od wyników symulacji w okresie od maja do sierpnia (było wiele dni z Solar Fraction $=1$ ). Maksymalna różnica wyniosła 20-50 punktów procentowych (Solar Fraction). Oprócz tego okresu nie zaobserwowano żadnych szczególnych różnic.

Dodatkowo przeprowadzono analizę osiągniętych różnic między zyskami ciepła słonecznego obliczonymi przez oprogramowanie symulacyjne Get Solar a wartościami rzeczywistymi (dla analizowanego budynku). Symulacja ta została wykonana przed procesem budowy instalacji.

SŁOWA KLUCZOWE: symulacje, energia słoneczna, OZE, płaskie kolektory słoneczne, ciepło solarne 